\title{
ŽENSKÝ SURCOT Z KRÁLOVSKÉ KRYPTY
}

\author{
MILENA BRAVERMANOVÁ
}

Textilně technologický průzkum Adéla Plátková

\begin{abstract}
Abstrakt: Čtyři ženy Karla IV. a prvni žena Václava IV. byly postupně pochovány do královské hrobky $v$ chóru sv. Vita v katedrále. Původně měly všechny královny každá svoji samostatnou rakev, po úmrtí Rudolfa II. († 1612) se jejich ostatky, společně s ostatky Václava IV. a Jana Zhořeleckého, ocitly v jedné schráně. V roce 1928, kdy došlo k zásadní úpravě hrobky, bylo v této schráně nalezeno značné množství látek, vesměs pozůstatků rouch.

V roce 2014 byly konzervovány jedny z ženských šati̊. Byly ušity z hedvábného lampasu. Půda tkaniny je dnes zelená, větši část rostlinného vzoru byla vytkána barevným lancé útkem dnes okrové barvy, některé detaily byly kdysi provedeny i zlatým útkem (pozlacený kožený řemínek bez duše). Látku lze vročit do 1. poloviny 14. století a byla zhotovena zřejmè ve Střední Asii. Ženské roucho bylo ušito z rovných dílů, do nástřihů na předním i zadním dílu byly vloženy klíny tvaru rovnostranného trojúhelníku. Ty byly také po stranách. Z rukávi̊ se zachoval jenom jeden, byl úzký a polodlouhý k lokti. Šlo tedy o svrchní ženský surcot. Vzhledem k dataci tkaniny i tvaru oděvu jej lze s otazníkem připsat Anně Svidnické.
\end{abstract}

Klíčová slova: královská krypta - Anna Svídnická - surcot s rukávy k lokti-lampas - Střední Asie.

\section{A Female Surcoat from the Royal Crypt}

Abstract: Four wives of King Charles IV and the first wife of Wenceslas IV were buried in the royal tomb located in the gallery of St. Vitus' Cathedral. Originally, each of the queens had her own coffin, but after the death of Rudolph II (†1612) their remains, together with those of Wenceslas IV and Jan Zhorelecký, appeared in a single case. In 1928 the tomb went through a major reconstruction, in the course of which it yielded a large amount of fabrics, chiefly remains of shrouds.

One of the garments was conserved in 2014. It was made of silk lampas. The fabric is now green, and the major part of the plant pattern was woven in colour lancé weft that is ochre, while some details were also made in gold weft (a gilded leather strap). The fabric dates from the first half of the 14th century and probably came from Central Asia. The garment was sewn together from straight sections, and the slits in the front and back contained wedges of fabric in the shape of equilateral triangles; these were also on the sides. One sleeve has survived: it was narrow and reached to the elbow. The garment is thus believed to be a female surcoat. The dating of the fabric and the cut of the garment indicate that it could be attributed, with a question mark, to Queen Anna of Schweidnitz.

Key words: royal crypt - Anna of Schweidnitz - surcoat with elbow-length sleeves - lampas - Central Asia.

V rámci systematického zpracování a vyhodnocení sbírky středověkého textilu z královské krypty z katedrály sv. Víta na Pražském hradě je nyní pozornost věnována ženskému surcotu.

\section{Nálezové okolnosti a inventář ženských rakví}

Dějiny královské hrobky byly poslední dobou detailně zpracovány a opakovaně publikovány (Bravermanová-Lutovský 2007; naposledy Bravermanová 2012, 228-234; Bravermanová-Březinová 2014, 299-313; Bravermanová-Březinová v tisku), proto bude nyní stručně věnována pozornost jenom osudu ženských rakví, nebot' surcot tvořil součást pohřební výbavy jedné z českých královen (k tomu především Bravermanová-Kloudová 2010, 203-222; Bravermanová-Leppin-Otavská 2011, 593-625; Bravermanová-Březinová 2014, 299-313).

Do staré královské krypty, založené Karlem IV. okolo roku 1350, situované v katedrále před chórem sv. Víta byly postupně, vedle panovníků a dalších rodinných příslušníků, pohřbeny Blanka z Valois († 1348), Anna Falcká († 1353), Anna Svídnická († 1362), Johana Bavorská 
(† 1386) a Alžběta Pomořanská († 1393). V roce 1590 byly ostatky českých králů a jejich příbuzných přeneseny do nově zbudované krypty více na západ, nad níž bylo postaveno nadzemní tzv. Colinovo mauzoleum. K velké změně v kryptě došlo v roce 1612, kdy po smrti Rudolfa II. byl do podzemní části postaven císařův objemný sarkofág. Kvůli tomu byly obsahy rakví žen Karla IV., první ženy Václava IV., Jana Zhořeleckého a Václava IV. vloženy do jedné schrány. Při tom zřejmě došlo k velkým ztrátám částí pohřebních výbav.

Hrobka byla v letech 1677, 1743, 1804, 1824 a 1851 navštěvována a několikrát byly i měněny rakve, přičemž docházelo k pomíchání ostatků i výbav. V letech 1928-1935 došlo k rozsáhlé rekonstrukci krypty a opět byly zhotoveny nové rakve. Pozůstatky Václava IV. (společně s pozůstatky Johany Bavorské) a Jana Zhořeleckého byly tehdy vloženy do samostatných schrán. Další rakev byla určena ženám Karla IV. Pohřební výbavy se od té doby staly součástí sbírek Pražského hradu.

V první polovině 20. století bylo publikováno několik článků, v nichž lze nalézt - na rozdíl od dřívějších dob - o látkách a rouchách z ženských pohřbů poněkud obšírnější informace. J. Cibulka píše, že „, rakvi manželek Karla IV. byl nalezen největši počet látek. Kromě nevzorovaného hnědého sametového pláště, zjevně pozdějšího pưvodu, nebylo látky, která by bezpečně nemohla existovat $v$ druhé polovici XIV. století. Druhou výjimkou byly dva malé kousky látky, vzorkované lineárně stylizovanými ptáky v kruzich. Ostatni látky z rakve Karlových manželek patři do XIV. století. Jsou tu ženské šaty se vzorem listu araceového se zlatými pruhy na ramenou a jiné šaty kolem krku zdrhnuté v souběžné plissé s malými dírkami kolem výstřihu, jimiž bylo protaženo poutko. Vedle těchto dvou šatů je tu tunika rázu spiše mužského, jejiž vzor tíhne spiše do XV. století. Kdož ví, nebyl-li to šat mrtvoly, která byla pohřbena jako Václav IV. Jiná látka je zdobena vzorem plachetni lodi, věc dosud neznámá, jiné přinášejí v odlišné stylizaci vzory dráčků, khilinů, fonghoangů, lotusových květů a palmet, tu symetricky podle osy komponovaných, tu v nepretržitém raportu jednosměrně za sebou běžicí. Většina jsou pưvodu italského, některé ukazují přesněji do Luccy, jako látky s věžemi, ale i tu je jedna látka aspoň podle vzorku pưvodu perského. Ze závojů českých královen zbyl jen malý kousek.“ (Cibulka 1928, 43)

V roce 1931 publikovala článek i M. Lejsková. Píše, že pozůstatky rouch, do kterých byly mrtvoly oděny, byly různým způsobem přeházeny a smíchány. Ze změti tkanin se dala částečně rekonstruovat dvě ženská roucha, i když se nedochovala v úplnosti. Živůtek prvních šatů byl přiléhavý a měl vpředu dírky a nitěné knoflíčky. Na zádech byly plisované pruhy látky připomínající křídla. Tato „křídla“ částečně zakrývala i předek živůtku. Rozšiřrenou sukni vypodšívkovaných šatů tvořily čtyři díly. Druhé, rovněž podšité šaty měly hladký střih, rozšířenou sukni a hluboký výstřih, který na jedné straně spínala zlatem protkávaná páska. Šaty se údajně velmi špatně zachovaly, např́iklad rukávy vůbec ne. Na přiloženém obrázku je naznačeno, že tyto druhé šaty byly na bocích přestřižené a nabíraná sukně byla nasazena zvlášt' (Lejsková 1931, 5-9, obr. 3-4). M. Lejsková však bohužel nenapsala, z jakých konkrétních tkanin byla tato dvě roucha ušita.

Další, kdo se pohřebními výbavami z královské hrobky zabýval, byla J. Gollerová-Plachá (1937). Autorka se věnuje popisu a uměleckohistorické interpretaci dvaceti vzorů, technologický rozbor tkanin tehdy proveden nebyl. Bohužel také, až na nepatrné výjimky, nebyl učiněn pokus ztotožnit nalezené tkaniny s oděvem konkrétních osob. J. Gollerová-Plachá k tomuto poznamenává, že při různých návštěvách hrobky byly textilie natolik přeházeny a promíšeny, že jejich identifikace podle původního nositele nebyla možná. V publikaci také nebylo naznačeno, jaký typ roucha byl z uvedených látek ušit.

V poslední době došlo ke ztotožnění několika tkanin z rakve královen, tak jak je popsal J. Cibulka i další, s pozůstatky mužských pohřebních rouch Václava IV. a Jana Zhořeleckého (k tomu např. Bravermanová-Lutovský 2007, 162-165). Co se týká ženských oděvů, byl interpretován živůtek šatů „se vzorem listu araceového“, který popsala i M. Lejsková jako zbytky druhého roucha hladkého střihu. K živůtku byla přiřazena také „zlatem protkávaná páska“ původně se nacházející na rameni. Oděv mohl patřit Anně Falcké (Bravermanová-Leppin-Otavská 2011, 597-604, 617-618; Bravermanová-Březinová 2014, 299-313). Jedné z českých králo- 
ven náležel i závoj se zvlněnými okraji (Bravermanová-Leppin-Otavská 2011, 604-619). Popis látky dalších nedávno rekonstruovaných ženských šatů bez rukávů a s klíny, s růžicemi a palmetami obklopenými dvojicemi různých zvířat, zřejmě spadá pod obecnou charakteristiku látek se „vzory dráčků, khilinů, fonghoangů, lotusových květů a palmet“, jak ji podal J. Cibulka. Roucho mohlo patřit Anně Svídnické nebo Johaně Bavorské (Bravermanová-Kloudová 2010, 203-222).

\section{Tkanina surcotu}

Právě zkoumané a konzervované ženské šaty byly ušity z látky zdobené výhradně rostlinnými motivy (Plátková 2014, obr. 1). Tkanina je hedvábný lampas, jehož základem je čtyřvazný osnovní kepr S tvořený základní osnovou a základním útkem. Osnovy i základní útek mají dnes tmavě zelenou barvu. Vzor je tvořen lancé útkem dnes okrové barvy, který váže s vaznou osnovou v plátnu. V tkanině byl také lancé zlatý útek, který se nedochoval, pouze jeho mikroskopické zbytky. I on vázal s vaznou osnovou pravděpodobně ve vazbě plátnové. Je určující, že vazná osnova v těch místech, kde původně procházel zlatý útek, vytváŕí ploché smyčky, kterými mohl provazovat jenom pozlacený kožený proužek, a nikoli zlatá nit’s duší kruhového průřezu. ${ }^{1}$ Pevný okraj je též vázán ve čtyřvazném osnovním kepru S, osnovy okrové barvy jsou zdvojené. Na vnějším kraji jsou dva svazky silnějších osnovních nití, které jsou provázány v plátnové vazbě. Okolo nich se otáčí hedvábný lancé útek, zlatý lancé útek byl zřejmě před krajem oříznut. ${ }^{2}$

Shodná vazba se nachází naprríklad na látce manipulu z kostela sv. Nikolaje v Stralsundu. V základu je též čtyřvazný osnovní kepr S, vzor je tvořen dvěma lancé útky, různobarevným hedvábným a pozlaceným koženým proužkem, které vážou s vaznou osnovou v plátnu. Tkanina je interpretována jako středoasijská z první poloviny 14. století (Stralsund, St. Nikolai; Fircks 2008, 93-95).

Vzor tkaniny z královské krypty se skládá ze dvou řad různých palmet, které jsou umístěny stř́idavě nad sebou. V jedné řadě jsou zobrazeny z čelního pohledu a jsou samostatné. Ve druhé řadě jsou vždy v páru a vykloněny do stran směrem od sebe. Palmety jsou propojeny zdvojenými stonky do tvaru srdce. Uprostřed srdce je palmeta zavěšená na dvojitém stonku. Nad ní je po každé straně na dvojitých stoncích hrozen stylizovaných květů (hrozen tvoří drobné kosočtverce vedle sebe, nikoli kroužky). Celý prostor kolem ústředních motivů je vyplněn drobnějšími rostlinnými motivy, převážně různými druhy lístků, které jsou dnes osamocené, původně však byly propojeny stonky. Kompozičně je také možno schéma vzoru popsat tak, že palmety jsou umístěny do linií ze stonků vytvářejících zašpičatělé ovály (obr. 2).

\footnotetext{
1 Pokud by byla duše hedvábná, alespoň v malé míře by se zřejmě dochovala. Pokud by byla z rostlinného vlákna, mohla se zcela rozpadnout, v každém případě však pozůstatkem po zlatém útku s duši by byly do oček povytažené vazné osnovy.

2 Technická definice vazby tkaniny:

-lampas, 2 lat de lancé, základ čtyřvazný osnovní kepr S 3/1

-osnova: 2 systémy osnov - hlavní a vazná

-poměr: 4 nitě hlavní osnovy : 1 niti vazné osnovy

-materiál: hlavní osnova - hedvábí, zákrut $Z$, dnes tmavě zelené barvy, průměr nitě 70-100 $\mu \mathrm{m}$

-vazná osnova - hedvábí bez viditelného zákrutu, dnes tmavě zelené barvy, průměr nitě $120-160 \mu \mathrm{m}$

-découpure osnovy: 1 vzorová osnova

-hustota osnovních nití: 60 nití hlavní osnovy / cm, 15 nití vazné osnovy / cm

-útek: 3 systémy útků - základní a 2 lancé

-pořadí útků:1 základní, 1 lancé, 1 lancé

-materiál: základní - hedvábí, bez viditelného zákrutu, dnes tmavě zelené barvy, průměr nitě 290-310 $\mu \mathrm{m}$

-1 lancé - hedvábí, bez viditelného zákrutu, dnes okrové barvy, průměr nitě 320-380 $\mu \mathrm{m}$

-1 lancé - pozlacená zvířecí kůžička, dnes chybí

-découpure útku: 1 passée

-hustota útkových nití: 14 passée / cm

-pevný kraj tkaniny: dochovala se šíre tkaniny $-93 \mathrm{~cm}$

-šíre pevného kraje: minimálně $4,5 \mathrm{~mm}$

-materiál: hedvábí, zákrut Z, zdvojené, dnes okrové barvy

-vazba: čtyřvazný osnovní kepr S 3/1, na vnějším kraji jsou dva svazky silnějších osnovních nití vázány v plátně, okolo nich se točí 1 lancé,

hedvábný útek, 1 lancé zlatý útek byl zřejmě před krajem ořiznut

-hustota osnovních nití pevného kraje: 25 osnovních nití / $0,5 \mathrm{~cm}$

-technický raport vzoru: výška $=13,5 \mathrm{~cm}$, šírka $=32 \mathrm{~cm}$

-výtvarný raport vzoru: výška $=27 \mathrm{~cm}$, šiřka $=32 \mathrm{~cm}$
} 


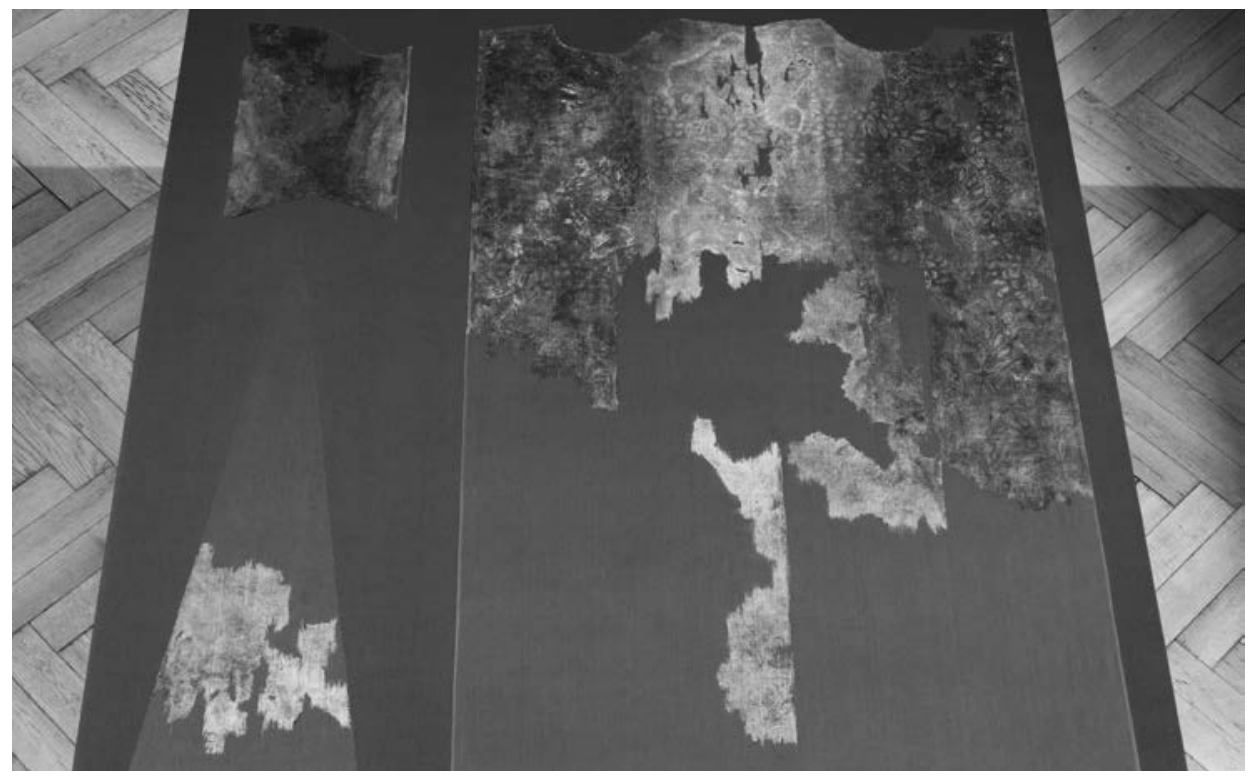

Obr. 1. Surcot po restaurování. Foto Jan Gloc, Fototéka Správy Pražského hradu.

Abb. 1. Der Surcot nach der Restaurierung. Foto Jan Gloc, Fotothek der Prager Burgverwaltung.

Půda tkaniny je dnes zelená, tato barva je zřejmě původní. Větší část vzoru byla vytkána barevným lancé útkem dnes okrové barvy (původní barva neznámá), některé detaily byly kdysi zlaté - kontury vykloněných palmet a hroznů, obrysy drobných rostlinných motivů a části stonků. Vzor je tedy dnes nekompletní. Pevný okraj má dnes okrovou barvu.

Nejbližší analogie ke vzoru se nalézá na lampasu s lotosovými květy obklopenými listovými úponky (obr. 3). Základ tkaniny je ve čtyřvazném kepru S, vzorující lancé útek z pozlaceného koženého proužku váže s vaznou osnovu v plátnu. L. Wilckensová jako místo jeho původu uvedla Přední východ a vročila jej do první poloviny 14. století (Berlín, Kunstgewerbemuseum; Wilckens 1992, 53, obr. 86). Rozvržením výhradně rostlinných motivů včetně samostatných palmet $\mathrm{v}$ jedné řadě $-\mathrm{v}$ druhé řadě jsou však místo do stran vykloněných palmet $\mathrm{v}$ páru umístěny listy, přičemž shodné je propojení stonky do tvaru srdce - připomíná naši tkaninu také lampas s palmetami, zkroucenými stonky a lístky, je interpretován bud' jako středoasijský (Wardwell 1988-1989, 105-106, obr. 32), nebo jako irácký z první poloviny 14. století (Wilckens 1992, 45-46). I zde je základ ve čtyřvazném kepru S, vzorující útek váže s vaznou osnovou ve vazbě plátnové. Rozdílné je však použití materiálů, nebot' základní útek je bavlněný a vzorující útek tvoří pozlacená zvířecí kủžička obtočená okolo bavlněné duše (jeden z fragmentů Berlín, Kunstgewerbemuseum, další např. Norimberk, Germanisches Nationalmuseum).

Obdobně rozložený rostlinný vzor vyplňující celou plochu a s většími listy umístěnými stř́idavě nad sebou (motivy však nejsou spojeny stonky, v desénu se navíc objevují drobní ptáci a ryby) se také nalézá na tkanině uložené v Abegg-Stiftung. Jde rovněž o lampas (v základu je atlas, ve vzoru kepr), zlaté útky však mají hedvábnou duši. Je interpretován jako perský či středoasijský z konce 13. až první poloviny 14. století (Otavský-Wardwell 2011, 250-251).

Na jednom z lampasů, z něhož je ušita dalmatika uložená v kostele sv. Nikolaje ve Stralsundu, je detail připomínající detail tkaniny z královské krypty. V základu je čtyřvazný kepr Z, vzor se stonky s květinami, palmetami a ptáčky je tvořen základním útkem (tzv. liseré) ${ }^{3}$ a dále dvěma vzorujícími lancé útky - různobarevným hedvábným a pozlaceným koženým proužkem. Vzoru-

3 Liseré efekt: flotování (vznášení se) každého lichého základního útku (Vocabulary 1979, 30). 


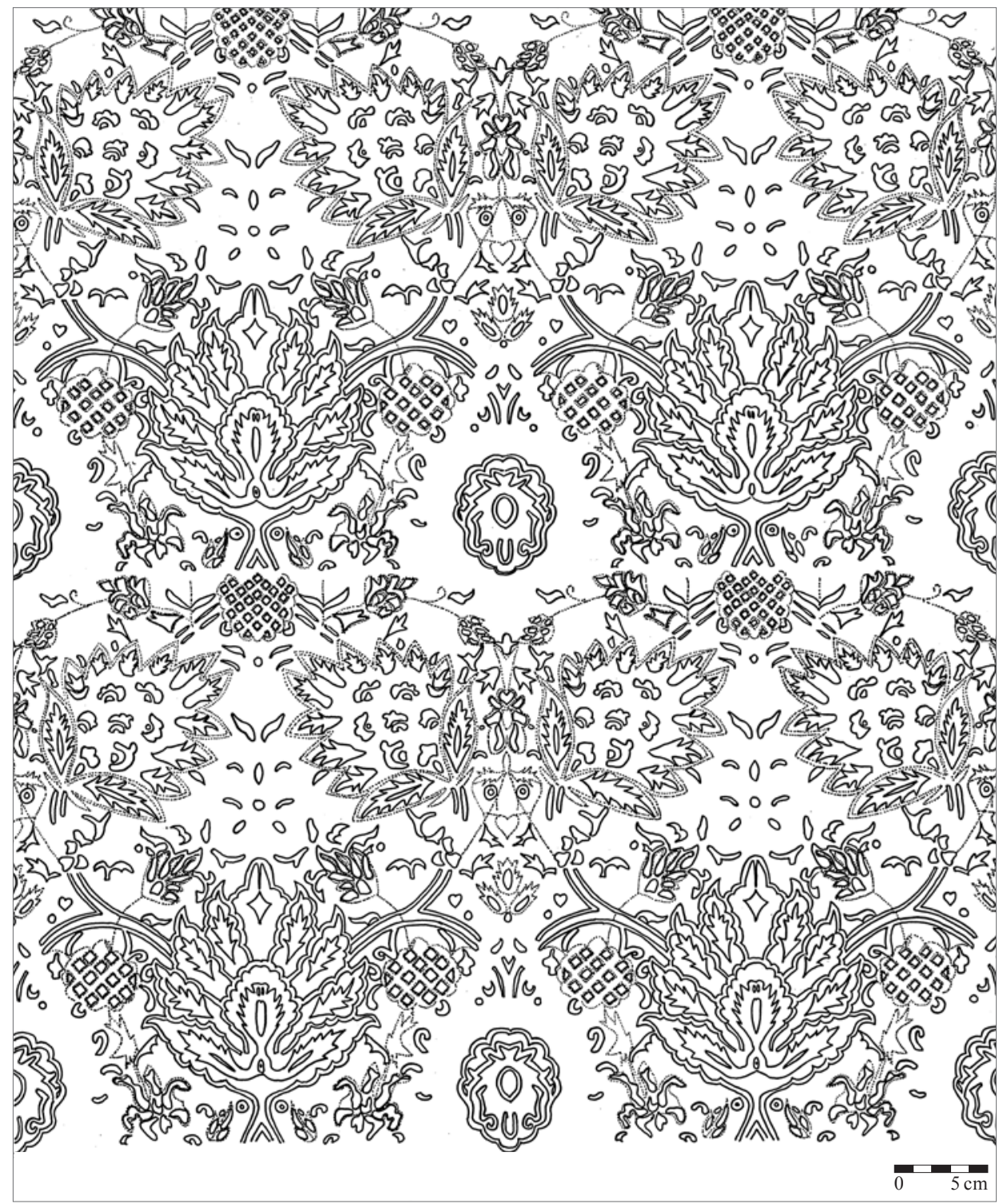

Obr. 2. Rekonstrukce vzoru. Kresba Adéla Plátková.

Abb. 2. Rekonstruktion des Musters. Zeichnung Adéla Plátková.

jící útky vážou s vaznou osnovou v plátnu. Efekt útků je tedy rozdělen tak, že vzory - palmety, květiny a ptáčci - jsou vytkány základním liseré útkem a různobarevným hedvábným vzorujícím útkem, detaily desénu, především stonky, malé lístky a další obrysy drobných rostlinných motivů a ptáčků, zlatým útkem. Tedy zlatý útek tvoří vzor v menší míře. Tkanina je interpretována jako středoasijská či severočínská z první poloviny 14. století (Stralsund, St. Nikolai; Fircks 2008, 73-91, př́edevším 76, 88). ${ }^{4}$

4 Obdobná tkanina pochází také z královské krypty. Její podrobné publikování je prripravováno. 


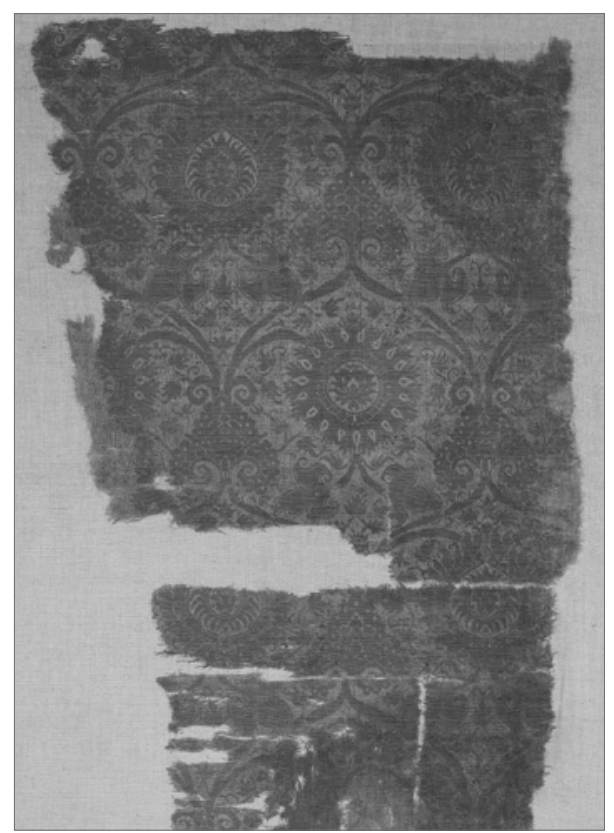

Obr. 3. Tkanina s lotosovými květy obklopenými listovými úponky uložená v Kunstgewerbemuseum v Berlíně. Staatliche Museen zu Berlin - Kunstgewerbemuseum. Foto S. Linke. Abb. 3. Im Berliner Kunstgewerbemuseum aufbewahrtes Gewebe mit von Blätterranken umgebenen Lotosblüten. Staatliche Museen zu Berlin - Kunstgewerbemuseum. Foto S. Linke.

\section{Středoasijské středověké tkaniny}

Popisované látky a jim podobné představují v textilním řemesle a umění specifickou skupinu. V jejich základu je kepr či atlas, ve vzoru plátno nebo kepr. Jsou tvořeny hlavní a vaznou hedvábnou osnovou se zákrutem $Z$ (je většinou $v$ poměru čtyři hlavní osnovy k jedné vzorové), základním hedvábným útkem většinou bez zákrutu (je 3-5krát tenčí než hlavní osnova) a hedvábným či kovovým vzorujícím útkem (mohou se vyskytovat oba). Hedvábný vzorující útek je bez zákrutu, kovový útek je tvořen pozlaceným proužkem zvířecí kůžičky bez duše (zlato je velmi čisté, někdy může být přimícháno i malé množství stř̌ibra, také může být jedna strana proužku pozlacena a druhá postř́ibřena). Osnovy v pevném okraji mají odlišnou barvu a jsou zdvojené, na konci okraje jsou dva svazky silnějších osnovních nití, kolem nichž se točí hedvábné útky, zlaté jsou většinou odříznuty. Šiřka tkaniny bývá 82-93 cm, ale jsou i výjimky. Tyto lampasy jsou považovány za stř̌edoasijské.

Technicky se částečně liší od těch, které mají základní útky bavlněné, a kovový útek je zhotoven tak, že pokovená kůžička je obtočena okolo duše, která je především bavlněná, pouze př́ležitostně hedvábná nebo lněná. Provenienčně je však i tato skupina látek zasazena do Stř̌ední Asie, případně východního Iránu.

Vzory, které uvedené tkaniny zdobí, jsou často rostlinné. Základem bývají hedvábnými, především však zlatými nitěmi vytkané palmety či lotosové květy v kartuších anebo umístěné stř́idavě nad sebou. Prostor mezi nimi je vyplněn malými rostlinnými motivy, často lístky, které jsou propojeny a pnou se tak, že vytvářejí i větší oválné tvary (ovály mohou být též zašpičatělé). Desén může být doplněn drobnými zvířecími postavami. Zvířata jako lvi, gryfové, sokoli či orli však mohou tvořit i ústřední motivy. Vzory bývají též uspořádány do podélných pruhů, v nichž jsou umístěny rostlinné a zvířecí ornamenty nebo i drobné geometrické prvky. Vyskytují se i nápisy pseudokufickým písmem.

Středoasijské desény ve 13 . a v polovině 14 . století byly též silně ovlivněny čínským výtvarným uměním s fantaskně podanými zvířcími (draci, ptáci, králíci, chobotnice) či rostlinnými motivy (lotosové květy; prostor byl také vyplněn obláčky), naopak palmety se do Střední Asie dostaly ze západu. Zlaté vzorující útky byly často na látkách velmi dominantní a jejich oslnivý vzhled poutal pozornost cestovatelů a dalších příchozích do zmiňovaných oblastí (Fircks 2008, 78-87; Wardwell 1988-1989, 95-173).

Velká část Asie byla ve 13. století a v první polovině 14. století pod nadvládou Mongolů, kteří ze svých původních sídel od počátku 13. století postupně opanovali tradiční textilní oblasti v Íránu a Iráku. Na východě si podmanili další hedvábnickou velmoc, západní a severní Čínu. Ve všech těchto oblastech docházelo k pohybu - často vyvolanému násilím - nejenom místního obyvatelstva, ale přicházeli sem i vojenské výpravy, karavany obchodníků, cestovatelé a misionáři. Stará textilní centra však proživala pod mongolskou nadvládou nový rozkvět a luxusní zboží v té době proudilo především po obnovené Hedvábné stezce. Situace se nezměnila ani po rozdělení Mongolské říše v roce 1260 na čtyři nástupnické státy v Číně, Střední Asii, Persii 
a jižním Rusku. Chanáty kromě Zlaté hordy nevydržely ani 100 let, po jejich rozpadu vznikaly na rozsáhlých územích různé místní vlády, především však od 80 . let 14. století říše turkického vojevůdce Tamerlána. Náporu Mongolů vzdorovali pouze Mamelukové v Sýrii (např. OtavskýWardwell 2011, 110-118).

Je tedy zřejmé, že v jednotlivých částech Asie docházelo po stránce textilní produkce k značnému vzájemnému ovlivňování, a to jak v tkalcovských technologiích, tak v dekorativním umění, které si příchozí často přinášeli ze své domoviny. Navíc obchodníci jistě převáželi nejenom hotové výrobky, ale i materiál, např́íklad kovové nitě.

Většina dochovaných středoasijských luxusních textilií se dnes nachází v evropských a severoamerických sbírkách, i když jde o zlomek tehdejší produkce. Soudobé zprávy o látkách dnes již z velké míry neexistujících se také nacházejí v písemných pramenech, především chrámových inventářích. V nich jsou stručně popsány tkaniny a co z nich bylo ušito, jenom výjimečně však obsahují upřesnění, v jaké oblasti či městě byly zhotoveny. Naopak písemné zprávy přímo z Asie, z nichž k nejvýznamnějším patří záznamy cestovatelů, jako byli Marco Polo, Ibn Battúta a Clavijo, či historika Rashída al-Dína, obsahují názvy tkanin či měst, kde se látky tkaly, avšak vyhýbají se popisu vzoru či textilně technologických detailů. Proto je dnes přesnější interpretace poměrně složitá (Wardwell 1988-1989, 95-97).

Evropské inventáře lehké orientální látky vytkávané zlatem nejčastěji pojmenovávají názvy nachum (nasetum, nashi, nasich, nasij, nac) a panni tartarici (odvozeno od obecného pojmenování Mongolské říše v Evropě Tartaricus). Tyto výrazy se v evropských inventářích objevují od konce 13. století a končí ve 14. století (Fircks 2008, 51-61, 80; Wardwell 1988-1989, 95, 134-144; Watt-Wardwell 1997, 127-138), v českých pramenech, především v chrámových inventáŕích svatovítské katedrály, kláštera svatotomášského v Praze na Malé Straně a kostela sv. Havla, od první poloviny 14. století do počátku 15. století. Písemnosti se zmiňují o jejich zvířecí, rostlinné i geometrické výzdobě, zaznamenávají však i složitější kompozice, př́ípadně prolínání více výzdobných prvků. Výraz pannus tartaricus se, na rozdíl od ostatních evropských, v českých pramenech objevuje méně, ty to látky jsou popisovány jako se zlatými pruhy či zvírecími motivy (Moravcová 1972, 136-140, 144).

Vzhledem k rostlinnému motivu tkaniny z královské hrobky jsou zajímavé popisy například v inventáři papeže Klimenta V. z roku 1311: „Item, unum supralectum de duobus pannis tartaricis viridibus, sutis per longum, laboratis ad pineas, vites et folia deauro“ (desén s lotosovými květy [palmetami?], úponky a lístky ze zlatých nití; Registi Clementis 436), v inventáŕi svatovítského chrámu z roku 1355: „Integer ornatus in nachone albo cum minutis foliis aureis, qui est vigiliae Paschae“ (desén s malými zlatými lístky; Podlaha-Šittler 1903, XIX, zápis č. 230) či v inventáři kostela sv. Tomáše v Praze na Malé Straně ze začátku 15. století: „Item duae cappae de panno nachonico in viridi campo cum virgulis aureis et floribus rotundis" (desén se zlatými proutky a okrouhlými květinami; Codex Thomaeus f. 119a).

Obdobné vzory jako ten, který se nachází na tkanině s rostlinným motivem z královské hrobky, jsou také zachycovány ve výtvarném umění. Malíri se při své práci inspirovali bud' skutečnými látkami, anebo se jim předlohou stávaly obrazy jiných malířů, kteří však měli existující tkaniny $\mathrm{k}$ dispozici. Je doloženo i obkreslování motivů ze skicářů. K usnadnění práce pomohlo tištění výzdobných motivů pomocí dřevěných šablon, tato technika přispěla $\mathrm{k}$ tomu, že se vzory na tkaninách ve výtvarném umění opakovaly na jednom obraze, u jednoho umělce a jeho dílny i u vzdálenějších okruhů ( $\mathrm{k}$ tomu Bravermanová 2003, 382-387).

Dekor s palmetami a stonky vytvářejícími zašpičatělé ovály a srdčité útvary (srdčité útvary jsou vykresleny pomocí stonků s drobnými zavěšenými lístky) se nalézá např́íklad na plášti Panny Marie na obraze Paula Veneziana Korunování Panny Marie (okolo poloviny 14. století, Benátky, Galleria dell'Accademia). V českém prostředí se obdobným desénem látek inspiroval Mistr Theodorik, když maloval oděvy postav v kapli sv. Kříže na Karlštejně. Palmety, rozety, drobné lístky a stonky úponků pokrývají celou plochu rouch sv. Kateřiny, sv. Anežky Ř́mské, sv. Markéty, sv. Voršily, sv. Víta, sv. Mořice, dvou sv. Biskupů a sv. Jiří. Přestože můžeme vypozorovat malé odchylky, např. někdy rozeta tvoří výplň palmety, jindy je součástí úponkového 
motivu vyplňujícího prostor mezi palmetami či některé detaily jsou provedeny plasticky, je dekor na všech rouchách velmi podobný. Jeho základem jsou výzdobné prvky provedené odlišnou barvou, než je půda tkaniny, především zlatou (Bravermanová 2003, 382-387).

Látku s rostlinným vzorem z královské krypty lze tedy podle výše uvedených ukazatelů vročit do první poloviny 14. století. Byla utkána zřejmě ve Střední Asii. Jako místo původu nelze vyloučit ani Persii, především kvůli kompozici vzoru. V tom případě by bylo možné, že zlaté nitě zhotovené z pozlacené zvířecí kůžičky a bez duše tam byly dovezeny.

Z královské krypty pochází daleko větší množství obdobně datovaných středoasijských a perských tkanin. Pohřební roucho Rudolfa I. Habsburského († 1307) bylo ušito ze dvou technologicky stejných, vzorem si velmi podobných středoasijských lampasů (v základu plátno, ve vzoru třívazný kepr Z) s motivy vytkanými pozlacenými, na druhé straně postř́ibřenými proužky kủžičky. Desén je ovlivněn čínským výtvarným uměním - na jedné látce jsou čínští draci a obláčky, na druhé ptáci držící v zobáku rybu (Bažantová-Bravermanová-Kobrlová- Samohýlová-Wasserbauer 1993, 359-377; Flury-Lemberg 1995, 174-199, 233-234). Také tunika, která byla zřejmě dána do rakve Václavu IV., když byl v roce 1424 pohřbíván na Pražském hradě, byla ušita z perské látky, datované do 13. až počátku 14. století (při tomto definitivním uložení ostatků tedy bylo vybráno zhruba 100 let staré roucho). Vzor lampasu s ptáky mezi úponky s lístky byl složitě vytkán, nebot' jej tvoří vzorovaná dvojitá látka (hlavní osnovy a základní útky vzorující podle potřeby měly vždy dvojí barvu) se zlatým útkem (pozlacený proužek zvířecí kůžičky obtočený kolem lněné duše; Flury-Lemberg-Otavský 1994, 293-304; Otavský-Wardwell 2011, 232-234). Z královské krypty však bylo dále vyzvednuto dalších osm středoasijských či perských látek, pozůstatek pohřebních rouch českých panovníků a jejich příbuzných. ${ }^{5}$

\section{Střih surcotu}

Z látky s rostlinným vzorem z královské krypty se dochovalo šest fragmentů různé velikosti. Dnes jsou křehké a potrhané, místy chybí celé soustavy nití. Zcela je zničen zlatý útek, dochovaly se z něj jenom mikroskopické částečky a otisky. Neuspokojivý stav tkaniny je také zapř́íčiněn nevhodným restaurováním Státních restaurátorských ateliérů v roce 1980, během něhož došlo nejenom k nešetrnému čištění, ale i k vypárání původních stehů (pokud v té době ještě existovaly) a rovněž pomíchání fragmentů, to vše bez pořízení patřičné dokumentace. V roce 2014 byly v restaurátorských dílnách oddělení uměleckých sbírek Správy Pražského hradu fragmenty nově konzervovány (Plátková 2014). ${ }^{6}$

Na největším fragmentu $(105 \times 93 \mathrm{~cm})$ je po obou stranách dochován pevný okraj, takže je možné určit šíři látky $-93 \mathrm{~cm}$. Jde o velkou část šatů, které byly střiženy tak, že v šířce tkaniny se nacházel přední i zadní díl, tzn. na jedné straně díly nebyly původně samostatné a poté $\mathrm{k}$ sobě přišité, pouze zde byl nastřižen průramek. Šev byl naopak na druhé straně, kde se také zachovalo několik zbytků hedvábné nitě. ${ }^{7} \mathrm{~V}$ horní části tohoto velkého fragmentu jsou dva mělké průkrčníky (vepředu, vzadu), od nichž jde kvůli snadnějšímu provlečení hlavy vždy jeden krátký průstřih. V průkrčnících však nejsou umístěny symetricky. Zhruba od poloviny fragmentu směrem dolů jsou další tři nástřihy (vepředu, vzadu a po straně), v nichž byly původně vsazeny klíny. $\mathrm{Na}$ ramenou jsou zachované dírky po stezích, je zjevná ledabylost. K dolní části tohoto velkého fragmentu byly přiřazeny ještě další dva menší $(56 \times 14 \mathrm{~cm}, 51 \times 23 \mathrm{~cm})$. Je na nich patrný střih.

\footnotetext{
5 Jejich podrobné zpracování a publikování se prripravuje.

6 Fragmenty hedvábné tkaniny byly pod stereomikroskopem a polarizačním mikroskopem podrobeny textilně technologickému průzkumu (vazba, použitý materiál), dále byla provedena rekonstrukce vzoru. Následně byly tvary fragmentů, jejich poškození a drobné detaily jako vpichy po stezích, švy a záložky a další zakresleny na melinexovou fólii, pro orientaci byla zde schematicky zaznamenána i část vzoru. Vzhledem k špatnému stavu fragmentů byla poté látka pod binokulární lupou jemně mechanicky vyčištěna štětečkem a prachové nečistoty byly lokálně odsáty vysavačem se sníženým odtahem. Pomocí ultrazvukového zvlhčovače na studenou páru byly dále přeschlé fragmenty navlhčeny a vyrovnány pinzetami ve směru osnov a útků. Následně byla na dřevěnou desku s gabonovou dýhou, potaženou moltonem a speciální šedočernou tkaninou, našita obarvená krepelína znázorňující předpokládaný tvar fragmentů tam, kde to bylo možné jednoznačně určit. Originální tkanina byla na tato místa uložena a na závěr překryta sklem.

7 Šicí nit’: hedvábí, zákrut S, průměr $388 \mu \mathrm{m}$.
} 


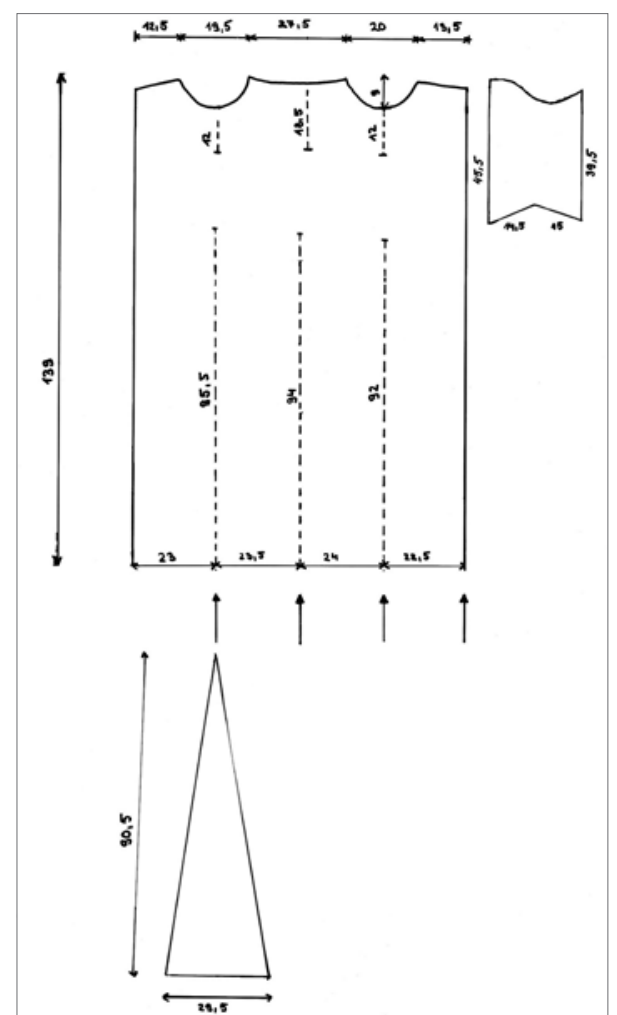

Obr. 4. Schéma střihu šatů, rozměry v centimetrech, šipky značí umístění klínů. Kresba Adéla Plátková.

Abb. 4. Schnittschema des Kleides, Maße in Zentimetern, die Pfeile kennzeichnen die Lage der Zwickel. Zeichnung Adéla Plátková.
Na dalších dvou fragmentech $(32 \times 18 \mathrm{~cm}$, $17 \times 12 \mathrm{~cm})$ jsou diagonální zastřižení, zṛ̌mě byly tedy částmi klínů.

Poslední fragment $(45 \times 28 \mathrm{~cm})$ má přibližně obdélníkový tvar. $\mathrm{Na}$ jedné $\mathrm{z}$ delších stran je pevný okraj, na protější straně jsou patrné stopy po švu. Kratší strany nejsou rovné. Jedna $\mathrm{z}$ nich je jakoby symetricky zastřižena dovnitř do tvaru odvěsen trojúhelníku, okolo střihu jsou dochovány stopy po založení a švu. Druhá kratší strana je zhruba v polovině délky střižena přibližně rovně, poté část chybí a dále rovné zastřižení pokračuje, ale je níže. I zde jsou stopy po švu, na vyšší části byl okraj podehnut zřejmě dvakrát. Tento fragment připomíná rukáv.

Po sestavení všech fragmentů do střihu se zjistilo, že vzhledem k rozměrům a tvaru šlo o ženské roucho. Šaty byly pořízeny z rovných dílů (na jedné straně od sebe neoddělených), do nástřihů na předním i zadním dílu byly vloženy klíny tvaru rovnostranného trojúhelníku. Ty byly také po stranách. Z rukávů se zachoval jenom jeden, byl úzký a polodlouhý k lokti (obr. 4). Je pravděpodobné, že v podpaží byl původně ještě vložen menší klínek. Trojúhelníkové zastřižení délky rukávu budí dojem, že zde byl cíp - z ikonografických pramenů víme, že se na ženském, ale i mužském gotickém oděvu někdy nacházel. Při ověření se však zjistilo - u vědomí toho, že šlo o pohřební roucho -, že v prŕípadě složených rukou nebožtíka na břiše, tak jak to bývalo v rakvi obvyklé, rukáv obepíná partii u lokte a cíp prakticky nevytváríi. Původní délka šatů je nezjištěna, byla však nejméně $139 \mathrm{~cm}$, délka rukávů je ca $45 \mathrm{~cm}$. Obvod přes hrud' (tedy před rozšířením pomocí vložených klínů) je ca $90 \mathrm{~cm}$ (je dán šiřkou tkaniny po odečtení šířky švů).

Základním prvkem střihu šatů jedné z českých královen jsou tedy dlouhé rovné pruhy látky tvořící přední i zadní díl, které byly od pasu směrem dolů rozstřiženy a do průstřihů a po stranách byly vloženy klíny. Takto se od doby románské konstruovala většina oděvů - košilí, tunik, cotte i surcotů -, které náležely mužům i ženám. Díky tomuto prvku se oděvy v spodní partii rozšiřovaly (např. Kania 2010, 133-164). Klíny vepředu, vzadu a po stranách se např́íklad nacházejí na dochovaných ženských vlněných oděvech z Herjolfsnaes (č. 38, 39, 40, 41, 42, 43, 44, 45, pozdní středověk, Kodaň, Nationalmuseets; Østergard 2004, 160-182) či na původně hedvábném světském oděvu, jehož část se posléze stala relikviářovou tkaninou, dnes v klášteře sv. Mořice ve Švýcarsku (středověk, St. Moritz; Schmedding 1978, 193).

U dalších dochovaných ženských oděvů se klíny nacházejí jenom po stranách. Takto byl konstruován pohřební spodní oděv (saya) a surcot (pellote) Leonory Kastilské (1244, Burgos, Santa Maria la Real de Huelgas; Vestiduras Ricas 2005, 170-173). Ze světského surcotu byl posléze přešit plášt' dnes připsaný sv. Birgittě (okolo 1300, Řím, S. Lucia i Selci; AnderssonFranzén 1975, 18-28), podobná historie se váže i k rouchu sv. Kláry z Asissi (okolo 1250, Asissi, Santa Chiara) a sv. Alžběty (okolo 1230, Eltville, Pfarrkirche; obojí Grönwoldt 1977, 407-417). 


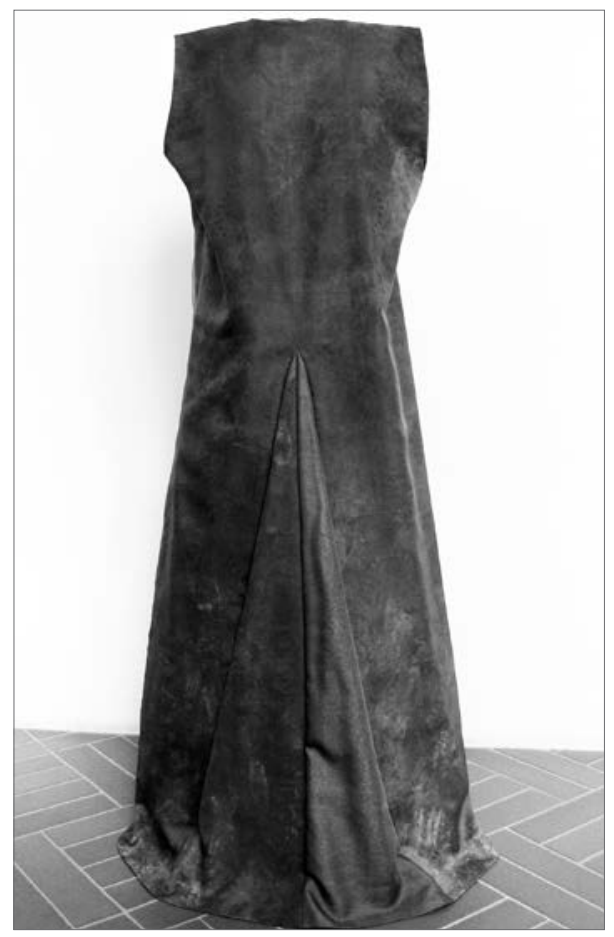

Obr. 5. Obdobné šaty z královské krypty: cotte nebo surcot, původně zřejmě patřící Johaně Bavorské. Foto Jan Gloc, Fototéka Správy Pražského hradu.

Abb. 5. Ähnliches Kleid aus der Königskrypta: offenbar ursprünglich Johanna von Bayern gehörende Cotte oder Surcot. Foto Jan Gloc, Fotothek der Prager Burgverwaltung.

\section{Středověká ženská móda}

Základními prvky středověké ženské módy vyšších tříd byly cotte, surcot a plášt'. Cotte byla původně spodní tunika - košilové oblečení, které se v pase stahovalo - postupně se však její živůtek stával těsnější, a naopak partie sukně se rozšiřovala. Rukávy byly úzké anebo se směrem k zápěstí rozšiřovaly. Cotte se zformovala i do tzv. cotte-hardie, ženského oděvu s hlubokým výstřihem, poměrně dost přiléhající (i pomocí knoflíků), s rukávy někdy ústícími v tzv. pachy (volně visící části rukávů či spíše falešných rukávů, přišité v ramenní nebo loketní části). Surcot byl svrchní oděv, něco mezi pláštěm a šatovou sukní. Původně byl poměrně široký a také se přepásával, postupně však začal mít podobnou siluetu jako cotte, neměl však rukávy anebo jeho rukávy sahaly maximálně k lokti. Pokud byl bez rukávů, průramky se postupně prohlubovaly (např. Boucher 1997, 176, 198-200; Davenport 1948, 151, 198-241; Houston 1996, 95-121; Kybalová 2001, 91-93, 122-222; Norris 1999).

V případě zmíněného zkoumaného roucha z královské krypty šlo vzhledem ke tvaru a rukávům k lokti o svrchní ženský surcot.

Nejbližší analogie ke střihu se nachází přímo na Pražském hradě. Z královské krypty byly $\mathrm{v}$ roce 1928 vyzvednuty i další téměr̆ kompletní ženské šaty. Byly ušity z lampasu s vytkaným vzorem růžic a palmet obklopených dvojicemi různých zvíratat. Látka je datovaná zhruba do třetí čtvrtiny 14. století. Živůtek ledabyle ušitých šatů byl hladký, sukně byla směrem dolů rozš́iřena čtyřmi vloženými lichoběžníkovými klíny, a to dvěma v průstřihu předního dílu a dvěma v průstřihu zadního dílu. Dochovaly se však jenom dva klíny. Zdá se, že oděv neměl rukávy, v tom prŕípadě by šlo o tzv. surcot. Anebo se rukávy během doby ztratily, byla by to tedy tzv. cotte. Zachované krejčovské detaily žádnou z těchto variant nepodporují, na druhé straně nelze zapomínat, že pohřební oděvy byly oblékány nebožtíkům, a tomu byl střih rouch a krejčovské detaily přizpůsobovány. Například šaty nemusely být před použitím zcela sešity, především v ramenních partiích, a aranžovaly se až na mrtvém těle (Bravermanová-Kloudová 2010, 203-222, obr. 5).

Přestože obojí šaty z královské krypty byly střihově obdobné, zřejmě netvořily pohřební odění téže královny. Surcot z lampasu s rostlinným vzorem je totiž menší, jeho obvod okolo hrudi je ca $90 \mathrm{~cm}$. Měl rukávy k lokti, pod ním tak musela být ještě tunika či cotte $\mathrm{s}$ dlouhými rukávy. Byl to tedy svrchní oděv. Surcot či cotte z lampasu s růžicemi a palmetami obklopenými dvojicemi různých zvířat, měl obvod hrudi ca $110 \mathrm{~cm}$. Pokud šlo o surcot, nebylo by logické vrstvit na sebe dva stejné typy odění. Pokud šlo o cotte, těžko by spodní oděv byl o ca $20 \mathrm{~cm}$ širší než svrchní. Navíc surcot s rukávy k lokti je ušit z látky nejméně o 30 let starší. ${ }^{8}$

8 Aranžmá surcotu k lokti z ženské rakve z královské krypty muselo být obdobné, jako je zachyceno na náhrobku Jone de Cobham († 1298) v kostele sv. Máŕi Magdalény v Cobhamu, Kent, z roku 1320 (obr. 6). 


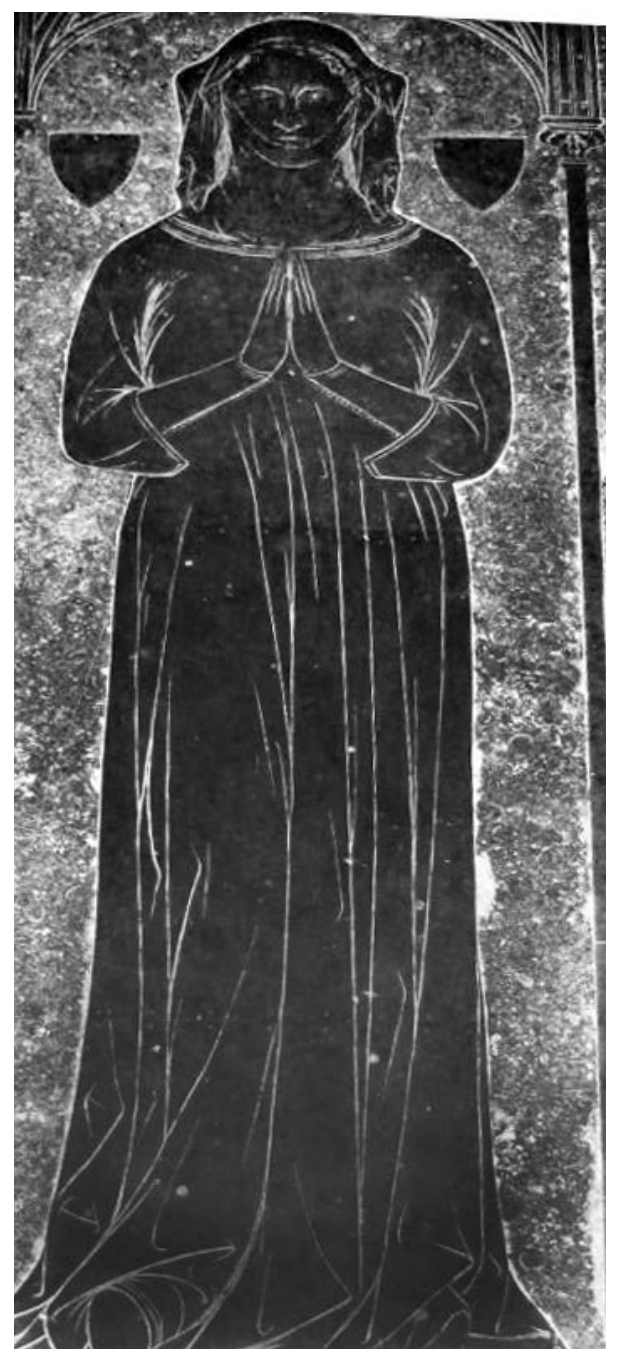

Obr. 6. Náhrobek Jone de Cobham († 1298), kostel sv. Máří Magdalény, Cobham, Kent, 1320. Foto archiv autorky. Abb. 6. Grabplatte von Jone de Cobham († 1298), Maria Magdalenenkirche, Cobham, Kent, 1320. Foto Archiv der Verfasserin.

\section{Interpretace}

Je otázkou, které české královně mohly šaty z lampasu s rostlinným vzorem náležet. Blance $z$ Valois asi patřily šaty vepředu sepnuté knoflíčky, ušité z lampasu s oválnými palmetami a dvojicemi ptáků a gryfů. Tkaninu je možné datovat do první třetiny 14 . století. ${ }^{9}$ Dále byl první manželce Karla IV. do rakve dán zřejmě plášt', na ramenou plisovaný a ušitý z lampasu středoasijské provenience se stonky s květinami, palmetami a ptáčky. I tuto, již výše zmíněnou, látku lze vročit maximálně do první poloviny 14. století (Bravermanová-Lutovský 2007, 162). ${ }^{10}$ Anna Falcká byla podle antropologického výzkumu vysoká jen $155 \mathrm{~cm}$ a velmi gracilní, proto je jí přisouzen živůtek šatů (ostatní části oděvu se nedochovaly) malých rozměrů (obvod hrudníku byl ca $80 \mathrm{~cm}$; Bravermanová-Leppin-Otavská 2011, 597-604). ${ }^{11}$ Přes tyto šaty (cotte?, musely by tedy být spodní a mít rukávy) měla Anna Falcká možná oblečeno svrchní roucho ušité ze tří velmi si podobných lampasů opět středoasijské provenience, na nichž jsou různě podané palmety. Tento oděv (cotte-hardie?) měl polokruhovou sukni částečně ústící do vlečky a rukávy s tzv. pachy. ${ }^{12}$ Vzhledem k časovému zařazení tkaniny s rostlinným vzorem bychom naopak zřejmě mohli vyloučit poslední manželku Karla IV. Alžbětu Pomořanskou († 1393), pokud by ovšem její roucho nebylo ušito z látky zhruba 80 let staré, což je však nepravděpodobné. Takže zbývají Anna Svídnická a Johana Bavorská. Anně Svídnické byl s otazníkem přisouzen surcot či cotte z lampasu s růžicemi a palmetami obklopenými dvojicemi různých zvířat (Bravermanová-Kloudová 2010, 218).

Po zvážení všech nových okolností a při úvaze, že surcot z lampasu s rostlinným vzorem a surcot či cotte $z$ lampasu s růžicemi a palmetami netvořily odění jedné královny, a s přihlédnutím k dataci obou tkanin, je možné provést určitou korekci. Surcot či cotte z lampasu s růžicemi a palmetami obklopenými dvojicemi různých zvířat lze spíše považovat za pohřební odění Johany Bavorské, a tedy právě zkoumaný surcot s rukávy k lokti z lampasu s rostlinným vzorem můžeme potom připsat Anně Svídnické. Je to však pouze určitá hypotéza, nebot' základním problémem je umístění všech ženských ostatků do společné rakve v roce 1612, a tím pomíchání všech výbav.

\footnotetext{
9 Zřejmě jde o šaty č. 1, tak jak je popsala M. Lejsková (1931, 5-9, obr. 3-4). Roucho bude v dohledné době konzervováno.

10 Viz pozn. 4.

11 Zřejmě jde o šaty č. 2, tak jak je popsala M. Lejsková (1931, 5-9, obr. 3-4).

12 Roucho bude $\mathrm{v}$ dohledné době konzervováno.
} 


\section{Prameny a literatura}

ANDERSSON, A.-FRANZÉN, A. M., 1975: Birgittareliker inlånade till Historiska museets utställning "Birgitta och det Heliga landet", 30 november 1973, 17 februari 1974. Antikvariskt arkiv 59. Stockholm.

BAŽANTOVÁ, N.-BRAVERMANOVÁ, M.-KOBRLOVÁ, J.-SAMOHÝLOVÁ, A.-WASSERBAUER, R., 1993: Textilie z hrobu Rudolfa I., českého krále, zv. Kaše - Die Textilien aus dem Grab Rudolfs I., des böhmischen Könings sgn. „Kaše“ (vorbericht), AH 18, 359-377.

BOUCHER, F., 1997: A History of Costume in West. London. Přetisk vydání Paris 1965.

BRAVERMANOVÁ, M., 2003: Tkaniny na rouchách postav zobrazených v kapli sv. Kříže. In: Dvorské kaple vrcholného a pozdního středověku a jejich umělecká výzdoba (Fajt, J., ed.), 114-123, 382-387. Praha.

- 2012: Pohřby a hroby lucemburských králů. In: Lucemburkové. Česká koruna uprostřed Evropy (Šmahel, F.-Bobková, L., edd.), 228-234. Praha.

BRAVERMANOVÁ, M.-BŘEZINOVÁ, H., 2014: Tkanice z pohřebních šatů jedné z českých královen zhotovená technikou tkaní na destičkách - Ein mit Brettchentechnik gewebtes Band vom Grabgewand einer böhmischen Königin, AH 39, 299-313.

- v tisku: Dětská tunika z královské krypty v katedrále sv. Víta.

BRAVERMANOVÁ, M.-KLOUDOVÁ, R., 2010: Pohřební šaty jedné z českých královen z královské hrobky v katedrále sv. Víta - Das Begräbniskleid einer der böhmischen Königinnen aus der Königsgruft im St. Veitsdom, AH 35, 203-222.

BRAVERMANOVÁ, M.-LUTOVSKÝ, M., 2007: Hroby a hrobky našich knížat, králů a prezidentů. Praha.

BRAVERMANOVÁ, M.-LEPPIN, B.-OTAVSKÁ, V., 2011: Fragment pohřebních šatů a závoj, tzv. kruseler, z rakve českých královen z královské hrobky v katedrále sv. Víta - Das Fragment eines Begräbniskleides und ein Schleir, ein sog. Kruseler, aus dem Sarg böhmischer Königinnen aus der Königsgruft im St. Veitsdom, AH 36, 593-625.

CIBULKA, J., 1928: Královská hrobka v Chrámě sv. Víta na Hradě Pražském, Umění II, 41-44.

CODEX THOMAEUS: Inventarium conventus Pragensis Divi Thomae apostoli. Codex diplomaticus. Státní ústřední archiv, řádový archiv augustiniánů, inv. č. 68, sign. III. A 51.

DAVENPORT, M., 1948: The Book of Costume. New York.

FIRCKS, J. von, 2008: Liturgische Gewänder des Mittelalters aus St. Nikolai in Stralsund, 137-143. Bern, Abegg-Stiftung.

FLURY-LEMBERG, M., 1995: Der Grabornat König Rudolphs I. von Böhmen. Riggisberger Berichte 3. Spuren kostbarer Gewebe, 174-199. Bern, Abegg-Stiftung.

FLURY-LEMBERG, M.-OTAVSKÝ, K., 1994: Die Grabgewand König Wenzels IV. In: Festschrift für Hermann Fillitz zum 70. Geburtstag. Aachener Kunstblätter des Museumsvereins, 293-304. Köln.

GOLLEROVÁ-PLACHÁ, J., 1937: Látky z pražské královské hrobky. Praha.

GRÖNWOLDT, R., 1977: Miszellen zur Textilkunst der Stauferzeit. Kaisergewänder und Paramente. In: Die Zeit der Staufer. Katalog der Austellung (Haussherr, R., hrsg.), 388-418, 607-644, obr. 566-598. Stuttgart.

HOUSTON, M., 1996: Medieval Costume in England and France. The 13th, 14th and 15th Centuries. Toronto, Ontario. Přetisk vydání London 1939.

KANIA, K., 2010: Kleidung im Mittelalter. Materialien - Konstruktion - Nähtechnik. Ein Handbuch. Köln - Weimar - Wien.

KYBALOVÁ, L., 2001: Dějiny odívání. Středověk. Praha.

LEJSKOVÁ, M., 1931: Dvojí šat královen z hrobky českých králů v chrámě sv. Víta v Praze, PA XXXVII, 5-9.

MORAVCOVÁ, M., 1972: Hedvábné látky v českých pramenech, Národopisný věstník československý VII, č. $1-2,131-161$.

NORRIS, H., 1999: Medieval Costume and Fashion. New York.

OTAVSKÝ, K.-WARDWELL, A. E., 2011: Mittelalterliche Textilien II. Zwischen Europa und China. Bern, Abegg-Stiftung.

ØSTERGÅRD, E., 2004: Woven into the Earth. Textiles from Norse Greenland. Aarhus.

PLÁTKOVÁ, A., 2014: Konzervátorská zpráva. Fragmenty ženských šatů (inv. č. PHA 4/9). Nevytištěno. Uloženo v dokumentaci oddělení uměleckých sbírek Správy Pražského hradu pod inv. č. PHA 4.

PODLAHA, A.-ŠITTLER, E., 1903: Chrámový Poklad u Sv. Víta v Praze. Praha.

REGISTI CLEMENTIS: Inventarium Thesauri Ecclesiae Romanae... Clementis Papae V, 1311, Registi Clementis Papae V, I. Appendices. Rome 1892. 
SCHMEDDING, B., 1978: Mittelalterliche Textilien in Kirchen und Klöstern der Schweiz. Bern, Abegg-Stiftung.

VESTIDURAS RICAS 2005: Vestiduras Ricas. El Monasterio de las Huelgas y su época 1170-1340. Catálogo de la Exposición. Responsable científico J. Y. Luaces. Madrid.

VOCABULARY OF TECHNICAL TERMS 1979: Vocabulary of Technical Terms. Fabrics. Lyon, Centre International d'Etude des Textiles Anciens.

WATT, J. C. Y.-WARDWELL, A. E., 1997: When silk was gold. Central Asian and Chinese Textiles. New York, The Metropolitan Museum of Art.

WILCKENS, L. von, 1992: Mittelalterliche Seidenstoffe. Bestandskatalog XVIII des Kunstgewerbemuseums. Berlin.

WARDWELL, A. E., 1988-1989: Panni Tartarici: Eastern Islamic Silks Woven with Gold and Silver (13th and 14th Centuries). In: Islamic Art. An Annual Dedicated to the Art and Culture of the Muslim World III, 95-147. Genova, New York.

\section{Zusammenfassung}

\section{Ein Frauensurcot aus der Königskrypta}

\section{Textiltechnologische Untersuchung Adéla Plátková}

In der von Karl IV. um das Jahr 1350 im Veitsdom vor dem Chor angelegten alten Königskrypta wurden neben den Herrschern und weiteren Familienangehörigen nacheinander Blanca von Valois († 1348), Anna von der Pfalz († 1353), Anna von Schweidnitz († 1362), Johanna von Bayern $(\dagger 1386)$ und Elisabeth von Pommern $(\dagger 1393)$ beigesetzt. Im Jahr 1590 wurden die Gebeine der böhmischen Könige und ihrer Verwandten in die neu errichtete, weiter westlich gelegene Krypta überführt. Eine große Veränderung erfuhr die Krypta im Jahr 1612, als in ihrem unterirdischen Teil nach dem Tod von Rudolf II. der Sarkophag des Kaisers aufgestellt wurde. Aus diesem Grund wurden die Gebeine der Frauen von Karl IV. und der ersten Frau Wenzels IV. sowie die von Johann von Görlitz und Wenzel IV. zusammen in einen Schrein gebettet. Im Laufe der Jahrhunderte wurde die Gruft mehrfach aufgesucht, wobei auch die Särge ausgetauscht wurden. Dadurch wurden sowohl die Gebeine, als auch die Grabbeigaben vermischt. In den Jahren 1928-1935 kam es zu einer umfangreichen Renovierung der Krypta, in deren Rahmen wieder neue Särge angefertigt wurden. Danach legte man lediglich die Gebeine wieder in die Krypta zurück und die Grabbeigaben wurden in die Sammlungen der Prager Burg aufgenommen. In letzter Zeit erfolgen deren Untersuchung und Konservierung.

Was die Frauenbekleidung anbelangt wurde bisher das Leibchen eines Kleides mit einer ursprünglich an der Schulter befestigten Borte konserviert und interpretiert. Das Kleidungsstück könnte Anna von der Pfalz gehört haben. Ferner ein ärmelloses, mit Zwickel versehenes Frauenkleid, das aus einem Stoff mit verschiedenen, von Rosetten und Palmetten umgebenen Tierpärchen genäht wurde. Dieses Gewand könnte Johanna von Bayern gehört haben. Einer der böhmischen Königinnen gehörte auch ein Schleier mit gewelltem Rand.

Das soeben untersuchte und konservierte Frauenkleid wurde aus Seidenlampas genäht, dessen Grundgewebe aus einem 4-bindigen, durch Grundkette und Grundschuss gebildeten S-Kettköper besteht. Kettfäden und Grundschuss haben heute eine dunkelgrüne Farbe. Das Muster besteht aus einem heute ockerfarbigen Schusslancé, der mit leinwandbindiger Kette bindet. In dem Gewebe befand sich auch ein Goldschusslancé, von dem lediglich mikroskopisch kleine Überreste erhalten geblieben sind und der ebenfalls mit leinwandbindiger Kette gebunden hat. Es ist bestimmend, dass die Bindekette an den Stellen, an denen ursprünglich der Goldschuss durchging, flache Schlaufen bildet, durch welche nur ein vergoldeter Lederstreifen und kein Goldfaden mit einer runden Seele eingeknüpft werden konnte. 
Die gleiche Bindung befindet sich beispielsweise auf dem Stoff des Manipels aus der Stralsunder Kirche St. Nikolai, der als zentralasiatisch und aus der ersten Hälfte des 14. Jahrhunderts stammend interpretiert wird (J. von Fircks).

Das Muster des Gewebes aus der Königskrypta besteht aus zwei Reihen unterschiedlicher Palmetten, die abwechselnd übereinander angeordnet sind und durch verdoppelte Stengel so miteinander verknüpft werden, dass sich herzförmige Gebilde daraus ergeben. In der Herzmitte ist die Palmette an einem Stengel aufgehängt, darüber befindet sich beidseitig jeweils eine Traube aus stilisierten Blüten. Der Raum um die zentralen Motive herum ist mit kleinen Pflanzenmotiven ausgefüllt. Der Gewebegrund ist heute grün, wobei es sich offenbar um die ursprüngliche Farbe handelt. Das Muster wurde größtenteils mit farbigem Lancé gewebt, dessen Schuss heute ockerfarbig ist (ursprüngliche Farbe unbekannt), einige Details waren einst goldfarben, so etwa die Konturen der nach außen geneigten Palmetten und Trauben oder die Umrisse der kleinen Pflanzenmotive und Stengelteile. Der feste Rand ist heute ockerfarbig.

Die ähnlichste Analogie zu diesem Muster befindet sich auf einem Lampas mit von Blattranken umgebenen Lotosblüten, das im Kunstgewerbemuseum von Berlin aufbewahrt wird. Als Herkunftsort des in die erste Hälfte des 14. Jahrhunderts datierten Gewebes wurde der Vordere Orient bestimmt (L. Wilckens). Durch die Anordnung der Pflanzenmotive erinnert auch ein ebenfalls im Berliner Kunstgewerbemuseum aufbewahrter Lampas mit Palmetten, gewundenen Stengeln und mit Blättern an unser Gewebe. Er wird entweder als zentralasiatisch (A. E. Wardwell) oder irakisch und als aus der ersten Hälfte des 14. Jahrhunderts stammend (L. Wilckens) interpretiert.

Diese und ihnen ähnliche Stoffe stellen im Textilhandwerk und in der Textilkunst eine spezielle Gruppe dar. In ihrem Fond ist Köper oder Atlas, im Muster Leinwand oder Köper. Sie bestehen aus einer bindigen Hauptkette aus Seide mit Z-Drehung, einem Grundschuss aus Seide meist ohne Drehung und aus einem metallischen oder seidenen Musterschuss (es können auch beide vorkommen). Der Musterschuss aus Seide ist ohne Drehung, der metallische Schuss besteht aus einem vergoldeten Tierhautstreifen ohne Seele. Die Kettfäden im festen Rand haben unterschiedliche Farben und sind doppelt, am Randende sind zwei stärkere Kettfädenbündel, um die sich die Seidenschüsse drehen, die goldenen sind meist abgeschnitten. Die Breite des Stoffs beträgt jeweils zwischen $82-93 \mathrm{~cm}$, jedoch gibt es auch Ausnahmen. Diese Lampas werden als zentralasiatisch angesehen.

Bei den Mustern, mit denen die hier genannten Gewebe verziert sind, handelt es sich häufig um Pflanzenmuster. Das Grundmuster besteht für gewöhnlich aus mit Seidenfäden - vor allem jedoch mit Goldfäden - eingewebten Palmetten oder Lotosblüten, der Raum zwischen ihnen wird mit kleinen - häufig aus Blättern bestehenden - Pflanzenmotiven ausgefüllt, die so miteinander verbunden werden, dass sie auch größere ovale Formen bilden. Das Dessin wird für gewöhnlich noch um kleine Tierfiguren ergänzt. Tiere können jedoch auch zentrale Motive bilden.

Der aus der Königskrypta stammende Stoff mit dem Pflanzenmuster kann demnach gemäß den oben aufgeführten Indikatoren in die erste Hälfte des 14. Jahrhunderts datiert werden. Er wurde offenbar in Zentralasien gewebt.

Nachdem alle Fragmente zum Schnitt zusammengefügt wurden, hat man festgestellt, dass es sich im Hinblick auf Maße und Form um ein Frauengewand handelte. Das Kleid wurde aus gleichen (auf einer Seite nicht voneinander getrennten) Teilen angefertigt, am Vorder- und Hinterteil wurden in die Zuschnitte dreieckige Zwickel eingesetzt, die auch an den Seiten vorkamen. Von den Ärmeln ist nur einer erhalten geblieben, er war schmal und halblang bis zum Ellenbogen. Die ursprüngliche Länge des Kleides konnte nicht festgestellt werden, betrug jedoch mindestens $139 \mathrm{~cm}$, die Ärmellänge beträgt ca. $45 \mathrm{~cm}$, der Brustumfang ca. $90 \mathrm{~cm}$ (gegeben durch die Stoffbreite von $93 \mathrm{~cm}$ nach Abzug der Breite der Nähte).

Bei dem soeben untersuchten Gewand aus der Königskrypta handelt es sich um einen Frauensurcot. Im Hinblick auf die Datierung von Stoff und Form des Kleidungsstücks kann es Anna von Schweidnitz zugeschrieben werden, obwohl das, im Hinblick auf die Unterbringung aller 
Frauengebeine in einem gemeinsamen Sarg und die dadurch zustande gekommene Vermischung aller Grabbeigaben, lediglich eine Hypothese bleibt.

PhDr. Milena Bravermanová, Správa Pražského hradu, Hrad, 11908 Praha, Česká republika, milena.bravermanova@hrad.cz 
